\title{
A Review of the Effectiveness of Crime Prevention by Design Approaches towards Sustainable Development
}

\author{
Massoomeh Hedayati Marzbali \\ School of Housing, Building \& Planning, Universiti Sains Malaysia, 11800 Penang, Malaysia \\ Tel: 60-17-447-1295 E-mail:mhm09_em0090@student.usm.my \\ Aldrin Abdullah (Corresponding author) \\ School of Housing, Building \& Planning, Universiti Sains Malaysia, 11800 Penang, Malaysia \\ Tel: 60-12-410-4715 E-mail: aldrin@usm.my \\ Nordin Abd. Razak \\ School of Educational Studies, Universiti Sains Malaysia, 11800 Penang, Malaysia \\ Tel: 60-17-455-9554 E-mail:norazak@usm.my \\ Mohammad Javad Maghsoodi Tilaki \\ School of Housing, Building \& Planning, Universiti Sains Malaysia, 11800 Penang, Malaysia \\ Tel: 60-17-405-8454 E-mail: jmaghsodi.rd07@student.usm.my
}

\begin{abstract}
Worldwide concern about population growth and rapid urbanization will continue to address crime as a social problem. The design of buildings and the arrangement of streets and other outdoor spaces can influence crime and level of fear of crime. Several studies related to sustainable development define it as reflecting a tension between economic activities and the environment. There has been little empirical evidence in the examination of crime and fear of crime as prerequisites for sustainability although in recent years, studies have concentrated on the consideration of crime as a sustainability indicator. Evidence suggests that reducing crime and fear of crime can improve the quality of life that is an essential factor in producing developments that are more sustainable. Previous research has focused on measures that are believed to be effective in reducing crime rates. Crime prevention, in truth, is to prevent crime before it happens. This approach is one of the most appropriate ways to save money and time that, in turn will be more sustainable in the long run. This article seeks to evaluate the objectives and effectiveness of crime prevention by designing strategies addressing socio-economic and environmental sustainability. The study makes use of available sources and data from previous studies and research. It argues that a secure and sustainable community must be defined by its image of a healthy community.
\end{abstract}

Keywords: Crime, Sustainable development, Built environment, Safety

\section{Introduction}

In light of the population growth and rapidly urbanization advances all over the world, crime has become one of the most serious social problems. In fact, governments and other authorities are trying to overcome this phenomenon by investing a lot of money as in prevention measures. However, this problem is still unresolved as crime rates around the globe continue to escalate. Tackling and reducing the negative impacts of crime on human life will inevitably lead to greater regulations and further invite more participation of both the individuals and the community. Therefore, it is important to think of alternative options to solve the existing problems. There is no doubt that crime is influenced by a multiplicity of factors such as economic, social, and governmental as well as physical elements (Newman, 1972). Meanwhile, the contribution of the built environment towards the reduction of crime has received considerable attention in the last four decades.

Designers and other design professionals should take into consideration the surrounding environment in order to reduce or enhance crime rates. The design of buildings and the arrangement of streets, public facilities and other outdoor spaces can affect the opportunity of crime and the level of fear of crime. Cozens, Saville and Hillier (2005, p. 343) defined a sustainable community as "safe, perceives itself to be safe and is considered by others to 
be safe". However, both sustainability and security are two important factors to be considered during the design process. Sometimes these two elements complement each other. In light of these considerations, mitigating crime and fear of crime may improve the quality of human life (Crowe, 2000; Schneider \& Kitchen, 2002) which is a basic human need. Safety and security have always been major human needs throughout history (Cozens, 2007a, 2008). Maslow (1970) proposed that the hierarchy of the most basic human needs includes five levels where safety needs is at the second level after physiological needs. The organizations of fortifications for castles such as defensive walls, landscaping and moats which were developed during the Middle Ages, have always tended to protect occupants from various threats (Cozens, 2008; Schneider \& Kitchen, 2002). It is, indeed, an essential task to produce developments that are sustainable. Evidence suggested that integrating physical safety in a project from the start rather than modifying it at a later stage can decrease design costs in the long-term (Crowe, 2000; Neill, Rueda, \& Savage, 2009). Therefore, architects, designers and planners should take security attributes into consideration in new developments at the planning and design stage.

In urban developments, sustainability issues can be addressed in different ways. Generally, early focuses on sustainable development defined it as reflecting a tension between economic and environmental objectives (Cozens, 2002; Du Plessis, 1999; Holtz, 1998). Societies should balance social, economic, and environmental objectives in order to ease the transition towards a more sustainable development (Soberon, 1998). The safety of the physical environment is also an integral part for the creation of sustainable development (Black, 2004). In recent years, studies have focused on some measures that are believed to produce more immediate results for the reduction of crime opportunities and consequently for the victimization rates. This article evaluates the physical characteristics of the environment in order to improve human conditions, environmental quality and the overall quality of life which are important components of sustainability. The aim of this article is to examine the effectiveness of crime prevention through design approaches towards sustainability objectives. It reviews the evidence and theories associated with safety and sustainability. In light of this consideration, the article examines three different aspects of sustainable development namely physical, social and environmental in relation to crime prevention approaches.

\section{Methodology}

This article mainly focuses on crime design strategies and in fulfilling the research objectives it seeks to evaluate its effectiveness and scope towards sustainable development. A survey of the literature for both sustainability and place-based crime prevention strategies was conducted. Several theoretical approaches are reviewed, and most successful and relevant approaches for each domain are recognized, and parallel points and challenges are identified as well. Recommendations are provided for adapting sustainability approaches for citizen's safety and well-being.

To study crime prevention objectives in relation to sustainability, the present study reviews available sources and data from previous studies and research including Armitage, 2007; Cozens et al, 1999; Cozens, 2002, 2007a, 2007b, 2008, 2009; Dewberry, 2003; Du Plessis, 1999; Knights et al., 2002, among others. The 2009 British Crime Survey provides a basis for studying the crime rate and opportunity to predict future crime trends. The methodological elements adapted in studies assessing sustainability are often more qualitative than quantitative in nature. It may seem to be difficult to make a comprehensive interpretation of sustainability aspects by means of numerical data and there is a need to embrace various levels of approaches due to the broad range of research areas. As for other qualitative studies, the article takes advantage of existing sources of data and researches. In this case, the study employs an aggregation method in the sense that the most relevant information is taken into account when it is impossible to examine the real number of such research projects due to the lack of an international database containing all the published studies on the topic. Thus, as a first stage, the research conducted hitherto was reviewed. Then, a summary of the different studies related to the field and the results that have been produced so far has been done. This is followed by a conclusion on the contribution towards sustainable development.

\section{Place-Based Crime Prevention Methods}

There is an increasingly awareness among society that humans and culture are components of the environment, whereas environment is inevitably linked with human health and environmental conditions (Jackson, 2003). As the amount of crime rate has been rapidly increasing all over the world, the crime prevention in urban areas has received a great deal of attention in recent years. The 2009 British Crime Survey (BCS) report indicated that 10.7 million crimes were reported in 2008/2009 (Walker, Flatley, Kershaw \& Moon, 2009). The findings show that our society needs to be aware against crime and fear of crime providing human health and safer communities. Therefore, it is important to explore methods to prevent crime in order to diminish the adverse effects of 
criminalities on human well-being.

According to Cozens (2002) the mapping of crime distribution was initiated in the midst of the nineteenth century. It was supported by Garland (1997) who stated that there was a long and continuous study of the so-called 'dangerous places' during the nineteenth century. It can be considered as a starting point towards developing crime prevention using design strategies. Crime prevention's methods and efforts to control crime through social and physical techniques skyrocketed during the 1970s. Greenberg, Rohe and Williams (1982) argued that there are two sets of investigations in regards to differences in crime rate among neighbourhoods. The first set of investigations is concerned with the physical characteristics of the environment such as the street pattern, the arrangement of buildings' layout and the diversity of the land use. The second area of study emphasized the social characteristics of the occupants, using variables such as residential stability, racial and economic composition and neighborhood change. Evidence suggested that both physical and social conditions may influence crime incidents, but the focus of the crime prevention by design studies lied on the influence of the physical factors. Regardless of the social characteristics, the physical form of the residence was shown to play an important role in reducing crime (Newman, 1996).

Several methods of practice and research have addressed the relationship between crime and place, which resulted in place-based crime prevention approaches. Together, it refers to the approaches that focused on modification and change of the physical environment in preventing crime. Crime is geographically concentrated as well as demographically (Higgins \& Millard, 2009; Sorensen, 2003). The 2009 BCS found that residents in urban areas are exposed to higher risk of being victims compared to residents in rural areas (Higgins \& Millard, 2009). In light of this consideration, there is no doubt that the design of the built environment and the arrangement of space can affect people's behaviour and crime opportunities. According to Nes (2009), human behaviour takes place in space, and the spatial layout of the environment provides various opportunities for people's interaction. The interaction between people can create safe or unsafe communities which are a foundational part of society's welfare.

In the USA, the National Crime Prevention Institute (1986, p.1-1), defines crime prevention as: "The anticipation, recognition and appraisal of a crime risk and the initiation of some action to remove or reduce it". In the context of place-based crime prevention, there is an extensive acknowledgement that architects, planners, landscape architects and designers can play an important role in the improvement of urban safety as they have a major influence in the design of the built environment. In the mid- $20^{\text {th }}$ century, theorists introduced a new way of exploring urban planning and rebuilding environmental spaces. Meanwhile, the National Institute of Justice (1997, p.3) interpreted the term place-specific crime prevention refers to "coordinated programs of change specifically, physical design, security, and property management changes that are targeted to a particular place and its problems" which retained a location centered focus. The earliest foundations of crime prevention by means of design can be traced as long ago as the 1960s and 1970s. It was initially grounded by Jane Jacobs (1961), author of 'The Death and Life of Great American cities', and later expanded by Jeffery (1971) as Crime Prevention Through Environmental Design (CPTED) and by Newman (1972) into what is known as 'defensible space'.

Jacobs (1961) claimed that diverse land use is a key factor in preventing crime. She suggests that neighbourhoods have many different functions such as residential, commercial, and leisure activities' centers. Due to diverse land use, there is an increased continual flow of people enhancing natural surveillance as an effective factor in preventing crime; this is the definition of what she presents as "a basic supply of activities and eyes" (Jacobs, 1961, p. 40). In a similar way, Newman's work concerns crime and space, indicating that spatial control by residents is the key factor for effective crime prevention in one area (Newman, 1972; 1980). Furthermore, Clarke (1997a) claims Newman's defensible space patterns providing a basic system to reduce crime vulnerability, especially catering to residential burglary. However, there are some contradictions between Jacobs' and Newman's theories that can be addressed to the different contexts in which the theories have been applied (Hedayati, Abdullah \& Maghsoodi, 2010). Poyner and Webb (1991) noted that the spatial layout of an area plays a key role in preventing residential burglary. Consistently, the study conducted by Shu (2009) suggested that types of street use and the degrees of road accessibility play an effective role in distribution of crime.

According to the National Institute of Justice (1997, p.4), there are three main components for place-specific crime prevention. The first component focuses on physical design changes which consists target-hardening, controlling access, increasing opportunities for surveillance, targeting crime 'hot spots' and improving image. The second component emphasizes on management changes includes revamping security (including policing), altering property ownership and/or management and expanding the role of residents. The last component refers 
to use changes which comprise increasing the use at different times of the day and the night, increasing the variety of business uses and increasing residents and others' usage for leisure activities. Therefore, it can be concluded that place-based crime prevention organizes the interaction among physical and social environment through modification and manipulation between three main components which are the design, the management and the use of a place. In the place-based crime prevention methods, there are four classical theories namely defensible space, crime prevention through environmental design (CPTED), situational crime prevention and environmental criminology (Schneider \& Kitchen, 2007) that are explained respectively in the following sections.

\subsection{Defensible space}

In the light of crime reduction by design features, the most influential study is perhaps the Defensible Space Theory established by Oscar Newman (1972). This concept was developed in the public housing environment by establishing a definite relationship among crime rates and urban design. It focuses on restructuring the physical layout of communities to allow residents to control the areas around the places where they live. It works by creating the physical appearance of a social bond that defends itself (Newman, 1972). Studies on defensible space approach led to the identification of those related physical strategies in terms of crime prevention that Newman called it as target hardening.

Newman (1972) extended Jacobs' (1961) ideas by proposing that the manipulation of the physical environment would largely influence the residents themselves. His work was to some extent contradictory to Jacob's work. He concentrated on territorial functioning in his defensible space model and focused more on the architectural approach of the residential area rather than on the urban planning approach and unlike Jacobs, who based her ideas on observation, Newman posits his theory based on empirical study.

According to Newman (1972), the combination of all the different elements such as indicators of territory and surveillance opportunities in order to create defensible space, have a common goal which is the responsibility to ensure a safe, productive and well-maintained living space. Furthermore, Newman (1972, p. 3) stated that "Defensible space is a model for residential environments which inhibits crime by creating the physical expression of a social fabric that defends itself". The Defensible Space Theory posits that the physical design of residential environment has a strong influence on both the crime incidences and the residents' fear of crime (Newman, 1972; 1982). Newman's Defensible Space Theory highly focused on the territorial functioning. In this case, territoriality involves the use of physical design to encourage a sense of propriety among citizens such as real barriers.

With regards to Newman's ideology, Welsh, Farrington and O'Dell (2010) suggested that among inner-city neighborhoods there is fairly strong evidence that Defensible Space techniques proved to be successful in reducing crime by means of street closures. Poyner and Webb (1991) adapted their studies from Newman's idea in a work entitled 'Crime Free Housing' in British suburbs and new towns. They argued that design faults of individual houses are an important factor influencing crime, when crime is a function of general patterns of layout (ibid., 1991). Clarke (1997a) claimed that Newman's defensible space provided a basic system to reduce crime's vulnerability, specifically focused on residential burglary. Several other studies also found that houses located or adjacent to major arteries with high accessibility contribute to the increase of residential burglary (Dietrick, 1977; Gardiner, 1978; Newman \& Wayn, 1974; Nutter \& Bevis, 1977; White, 1990) which are consistent with the defensible space theory. Despite of different viewpoints on crime and spatial layout, Clarke defined Newman's defensible space as the fundamental theory to protect premises against crime by enabling residents to control the surroundings of their own dwellings (Clarke, 1977a, 1977b).

\subsection{Crime Prevention Through Environmental Design}

The notion of Crime Prevention Through Environmental Design (CPTED) appeared in a 1971 book by criminologist and sociologist C. Ray Jeffery. Many of the elements in this approach are similar to the defensible space theory, which focuses on design solutions in reducing or preventing property crimes. The theory is based on the argument that most crime events are associated with the opportunities created by environmental design, meanwhile the CPTED approach is on the basis of reducing opportunity, which aims to manipulate the built environment in order to affect users' behaviour that will reduce crime and the fear of crime (Cozens, 2007b). CPTED is assumed on the hypothesis that "the proper design and effective use of the built environment can lead to a reduction in the fear of crime and the incidence of crime, and to an improvement in the quality of life" (Crowe, 1991, p.1). Furthermore, CPTED is the design or re-design of an environment to reduce crime opportunity and fear of crime through natural, mechanical, and procedural means (Sorensen, 2007). The study conducted by Parnaby (2007) revealed that today's CPTED proponents claimed that modifying environmental 
design can reduce opportunities of criminal acts, mitigate fear of crime and provide a better quality of life to improve human health. A study of council housing estates in Sheffield, UK found that there is a significant negative relationship between territorial functioning as a crime prevention strategy and victimization, indicating that high territoriality is associated with less crime experience (Abdullah, 1999). Hedayati (2009) conducted a similar survey in Penang, Malaysia. It was found that the CPTED approach has been helpful to negatively influence crime.

The strategies employed in this approach are: natural surveillance, natural access control, territorial reinforcement and maintenance (Cozens, 2002; National Institute of Justice, 1997; Parnaby, 2007). The first two strategies, natural surveillance and natural access control, are mainly geared towards promoting the offenders' risk perception by keeping users and outsiders under observation and denying access to potential targets. On the other hand, territorial reinforcement and maintenance are based on the assumption that the design and management of the environment can help the user of a property to feel a sense of ownership over a territory.

These four key elements provide the means to engender particular activities and decrease more deviant forms of activity (Haigh, 2006). The Natural Surveillance concept refers to the arrangement of physical design features involved with the activities and the people in order to maximize opportunities for surveillance at the right moment in time and space, consequently leading to crime discouragement (Cozens, 2002). Activity support refers to kinds of design that can be encouraged using public areas. This concept refers to the fact that offenders prefer those places with less observational control. It suggests that landscaping features can be designed to foster natural surveillance from within the home premises by residents and at the same time from the exterior by passers-by and neighbors. Natural access control involves the managing of a design to control the ingress and egress of persons to and from a specific space (Parnaby, 2007). This approach focuses on the management and design strategies in order to direct pedestrians and vehicular traffic to an easy flow, simultaneously discouraging criminal activities (Cozens, 2002).

Territoriality focuses on creating residents recognizable and identifiable zones within communities, so that people would feel connected and, thus, would attempt to defend their own community (Geason \& Wilson 1989). It involves the use of physical design to encourage a sense of propriety among citizens while, at the same time, creating environments where the perceived probability of resident intervention is high (Crowe, 2000; Newman, 1972; Parnaby, 2007). In terms of housing design, the concept of 'territoriality' can be enhanced to discourage criminality through using real and symbolic barriers to define space and property as being private or public zones (Cozens, Hillier \& Prescott, 1999). The image of development can encourage or discourage crime, which means that it can offer increased perceptions of vulnerability or isolation by way of design and maintenance (Cozens et al., 1999).

\subsection{Situational crime prevention}

This approach is based on the Opportunity Theory of Crime Prevention which was developed during the 1970s (Knepper, 2009). Situational crime prevention was initiated by Mayhew, Clarke, Sturman and Hough (1976), and Clarke and Mayhew (1980) in their work for the UK Home Office Research Unit, and also by Canadian researchers Brantingham and Brantingham in 1981 (Geason \& Wilson, 1989). Indeed, it is a general approach in reducing opportunities for any kind of crime, occurring in any kind of setting (Clarke, 1997a) which contributes to social welfare (Knepper, 2009).

Crowe (2000) suggested that the Situational Crime Prevention concept is more comprehensive than CPTED, because it unifies other law enforcement and crime prevention strategies in an attempt focusing on place-specific crime problems. Situational crime prevention is defined as "... a preventive approach that relies, not upon improving society or its institutions, but simply upon reducing opportunities for crime" (Clarke, 1992, p. 3). It applies at micro-scale and emphasizes on location and specific crime (Mora, 2008). In addition to design concerns, the theorists focus on legal and management issues, thus, this crime prevention method can comprehensively respond to some limitations of other crime prevention methods (National Institute of Justice, 1997).

\subsection{Environmental criminology}

Environmental Criminology derived from the work of Brantingham and Brantingham (1981). This analytical framework is concerned with the characteristics of crime events. Brantingham and Brantingham (2001) have noted that for any crime to occur, some factors must happen simultaneously: the victim or target, the specific location, the legal setting, and the technical or mechanical requirements of the crime. It has been defined (Bottoms \& Wiles, 1997, p. 305) that: “... the study of crime, criminality, and victimization as they relate first, to particular places, and secondly, to the way that individuals and organizations shape their activities by 
placed-based or spatial factors". Brantingham and Brantingham (1998, p. 53) considered the environmental criminology within the planning process which argued that "most of planning proceeds with little knowledge of crime patterns, crime attractors, crime generators, the importance of edges, paths and nodes or the site specific solutions that facilitate or even encourage crime". They considered the environmental criminology within the planning process. Generally, this concept further focuses on investigation on nonresidential land uses through two particular categories in relation to land uses: crime attractors and crime generators (Brantingham \& Brantingham, 1993; Rhodes \& Conly, 1981).

There are some similarities and differences among these aforementioned crime prevention strategies. With reference to the similarities, both CPTED and Situational Crime Prevention approaches are focused on reducing and eliminating crime through design. In addition, for both CPTED and Defensible Space, territoriality is a key element in enhancing community safety (Saville, 2009). Meanwhile, the Secured by Design (SBD) approach was initiated in UK in 1989 and developed by the Association of Chief Police Officers (ACPO). Its aim is to control new housing developments according to Defensible Space and CPTED features in order to decline crime opportunities. Taken as a whole, all SBD studies have concluded that it is an effective component in reducing crime and the fear of crime (Armitage, 2000; Armitage \& Monchuk, 2009 among others). Furthermore, cost-effective is suggested as one of the key benefits of the SBD scheme (Armitage, 2000) as well as better social well-being. Although SBD employed all these four crime prevention approaches, Cozens and Love (2009) argued that it takes into consideration Newman's Defensible Space theory and largely encourages less permeability as opposed to New Urbanism policies that support high permeability in order to achieve the sustainability agenda.

As indicated in Figure 1, Schneider and Kitchen (2002) summarized major stream in the development of crime prevention by design strategies. Although all crime prevention by design theories have been independently developed based on different approaches, it is clear that there is an overlap between one another because of the similarity of their supporting concepts. Much of the theoretical approach of CPTED is based upon Newman's Defensible Space. As depicts in Figure 1, Crowe's idea and the US National CPTED Training approach in terms of the creation of CPTED concepts are mostly influenced by Newman's Defensible Space theory.

Jacobs' study of the life cycles of major American cities is more concerned with macro-scale planning such as commercial and business settings, while Newman's work focused on micro-scale settings such as public housing and residential. Besides having a larger scale of CPTED rather than Defensible Space, it needs to be noted that CPTED features extend across all land uses. The fundamental CPTED principles are similar to the Defensible Space theory embraced by Newman such as surveillance, boundary definition, and access control. Evidence suggested that the focus of territoriality among CPTED proponents is less than Defensible Space practitioners. Maintenance also seems to be an important CPTED principle (Schneider \& Kitchen, 2002). Situational Crime Prevention is influenced by both CPTED and Defensible Space theories as well as by routine activity and rational choice theories (ibid., 2002).

\section{Safety and sustainability}

The concept of sustainable development emphasizes on equity between socio-economic activities with the environment which leads to enhance quality of human life (Berke \& Conroy, 2000; Kaiser, Godschalk \& Chapin, 1995). Cozens et al., (1999) argued that the application of the sustainable development concept focused on three strands namely environmental, social and economic sustainability. Campbell (1996, p. 306) defines sustainable development as "the long-term ability of a system to reproduce". By this definition, planners and designers should take into consideration the character of the future development. In light of the concept of sustainability in terms of balance among socio-economic and environmental values, Kaiser et al.,(1995) noted that an appropriate balance must exist among these sometimes complementary and sometimes competing values.

Makarov (2010) claims that today's sustainability is not only about ecologically sustainability, but it relates to social and economic aspects of human development. Public participation should also take into consideration the decision making process. Mega (1996) claimed that "link local to global concerns" must be considered as an aspect of sustainability in the development process. On the other hand, sustainable development is a dynamic process (Maclaren, 1996; Shepard \& Ortolano, 1996). All development activities among communities must encourage and move the community activities in the direction of becoming a more sustainable and liveable environment. Berke and Conroy (2000, p.23) suggest six basic principles for adapting developments to be more sustainable namely: harmony with nature, livable built environments, Place-based economy, equity, Polluters pay, and responsible regionalism. However, these principles lead to conclude that the development activities should protect biodiversity, enhance social cohesion, meet the needs of communities, and bring social welfare by using 
some basic elements in design and built environment.

As noted earlier, sustainability has usually been seen as an environmental and economic issue which failed to take into account crime and fear of crime issues (Glasson \& Cozens, 2010). There is a common misunderstanding of sustainability as 'green', while it needs to be highlighted that the key point towards sustainability must always emphasize on social, environmental and economic sustainability at the same time (Armitage \& Gamman, 2009). There have been limited empirical studies focusing on crime as a dimension of sustainability (Coaffee \& Bosher, 2008; Cozens, 2002, 2008; Du Plessis, 1999) but there are significant opportunities for such 'sustainable urbanism' to be ordinary in the future (Coaffee \& Bosher, 2008). The term sustainability should not only be interpreted as environmentally friendly, but it should also focus on creating safe, attractive and ecologically rich environment (Edwards, 2000). Accordingly, Srinivasan, O'Fallon and Dearry (2003) commended that there is a sparse research concerning sustainable communities by considering diligent planning as an essential factor to create natural, mental and physical human well-being. Sampson and Raudenbush (1999) argued that crime is considered as a mirror of the quality of life and a component of public well-being. Urban planning professionals have a pivotal role in the promotion of sustainable development by affecting the built environment (Glasson \& Cozens, 2010). They must focus on balancing and unifying the cultural, economic, physical and social contentment of people and, thus, confidently understand social malaise of crime and take into consideration safety of the surrounding environment and other social aspects of the environment in their design. It is proposed that urban sustainability is seriously undermined by crime and the fear of crime (Cozens, 2007a).

In recent years, the design of crime strategies appears in the creation of urban sustainability. Such strategies enhance the maintenance and the use of space and discourage the criminalities (Wilson \& Kelling, 1982). Devon County Council (2000) defines that a "sustainable community would be one in which people live without fear of crime, or persecution on account of their race, gender, sexuality or beliefs" (Schneider \& Kitchen, 2002, p. 27). Evidence suggests that the consideration of crime-free should be one of the principal human needs in providing sustainability. Carmona (2001, p. 167) among others argued that "...safe and crime-free human contact" is necessary to achieve sustainability. Srinivasan et al., (2003) in their study about creating healthy communities in the US have consistently revealed that a significant relationship between a deteriorated physical environment and high crime rate exists, leading to neighbourhood walkability decline and, as a consequence, resulting in higher social isolation.

Armitage and Gamman (2009) conducted a study entitled 'Sustainability via Security: A New Look', and they highlighted that security is a route towards sustainability. They further argued that the interpretation of 'sustainability versus security' has not considered security as an agenda towards sustainability. Moreover, in a study about 'Reconciling Security with Sustainability', Armitage and Monchuk (2009) indicated that there are no sustainable design features which makes it difficult in achieving SBD applications. Saville (2009) in his work entitled 'SafeGrowth: Moving Forward in Neighbourhood Development' emphasized on the issues faced in maintaining crime prevention features in the long run and indicated that the key of SafeGrowth refers to the shift with respect to a new style of user centred prevention (Armitage \& Gamman, 2009). Saville (2009) further concludes that reducing crime and enhancing community involvement are effective and sustainable aspects for developing and redeveloping urban environment for years to come.

Furthermore, Black (2004, p. 8) stated that "security is an integral part of sustainability, and it is generally essential if people are to achieve their full potential". Dewberry (2003) in her work entitled 'Designing Out Crime: Insights from Eco-design' considered both crime and sustainable development as social and environmental problems. As shown in Table 1, she suggested various synergies of crime prevention and sustainable development such as shared objectives, responsibilities and enhancements.

Evidence suggested that the impact and extent of CPTED is recently seen in terms of synergies between urban sustainability and CPTED (Du Plessis, 1999; Cozens, 2002, 2007a, 2008; Vanderschueren, 1998). Meanwhile, it is claimed that a synthesis of CPTED and urban sustainability approaches may lead the appearance of a 'sustainable urban environmentalism' in the light of the design, implement and maintenance of a safer urban landscape and more liveable communities (Cozens, 2002). CPTED, it is argued, can provide potential benefits of public health by means of risk assessments and delivering safer communities which tends to support active citizens, walkable communities and bring public health (Cozens, 2007b).

On the other hand, economic aspects should also be considered in the pursuit of sustainable development. Cozens (2007a) noted high financial costs of crime to the community, although mostly emotional and psychological, and the costs of fear of crime have not been explicitly evaluated. As noted earlier, evidence 
suggested that if crime prevention strategies are employed at the early stage of each development, it would be cheaper than employ them at later stages, as well as prove effective in reducing costs for the tackling of crime. Schneider and Kitchen (2002) in their work entitled 'Planning for Crime Prevention' used two study areas in the USA and Britain to explain the effectiveness of the design of the built environment on crime prevention in all aspects. They noted that it is proposed to be less costly to install crime prevention by design strategies such as surveillance and access control features in the initial design of developments rather than to retrofit buildings. Furthermore, they considered 'natural' surveillance and access control applications to be more sustainable (ibid., 2002).

\section{Conclusion}

In recent years, the rapid urbanization growth has caused various social, environmental and security challenges. Crime and the fear of crime are serious issues confronting societies and contribute to decline the quality of life. To solve these problems, a sustainable development viewpoint has risen to the fore. From early prehistoric cave-dwellers to medieval and modern cities, the organisation of settlements has always tended to provide security and safety as major human needs (Cozens, 2007a). In the long run, the aim of sustainability is to enhance the quality of life and to preserve the natural environment for future requirements.

We must bear in mind that "if planning is about making places better for people, then it has to address those elements that make places problematic for people, and crime and the fear of crime are high up in this list"(Schneider \& Kitchen, 2007, p. 233). Security and perception of safety are important factors for achieving sustainable development which are decreasing in recent years as Brantingham and Brantingham (1998, p. 53) stated that "most planning proceeds with little knowledge of crime patterns, crime attractors, crime generators, the importance of edges, paths and nodes or the site specific solutions that facilitate or even encourage crime". However, there has been little empirical evidence in the examination of crime and fear of crime as prerequisite for sustainability (Cozens, 2007a, 2008). Several studies have found different ways to solve the safety problems among urban areas. While planners, landscape architects and designers attempt to solve criminalities using their influence on the built environment.

In sum, from the literature on place-based crime prevention approaches and sustainable development, it can be stated that these approaches have made substantial strides in explaining the key characteristics of the environmental sustainability concept. The studies conducted by Jacobs (1961), Newman (1972), and Berke and Conroy (2000) among others show that spatial layout and type of land uses affect the vulnerability of residents against burglaries. Significantly, it is clear that crime prevention by design strategies may be able to cover all three components of sustainability and provide a balance among such components. Thus, place-based crime prevention approaches help to enhance sustainability in developments as well as safety of society. As Cozens (2007a) recommended, crime and fear of crime measures need to be considered as integral components of urban sustainability. Furthermore, designing out crime approaches are highly in line with environmental, social, as well as economic sustainability. However, such environmental approaches can lead to better quality of human life and also public cohesion which are fundamental elements for a sustainable development. One possible explanation is that neighbourhood environmental design can possibly be manipulated on the basis of crime prevention strategies to achieve crime reduction and ultimately, better quality of life and sustainable communities.

Important conclusions that can be drawn from this study are connected with the initial research objectives. Clearly the reviews reported in this article provide empirical evidence supporting the significant relationship between safety and sustainability. The present paper suggests that the application of crime prevention principles have positive effects in the built environment and possess low levels of crime and fear among societies. Consequently, it can be pointed out that place-based crime prevention strategies appear to be effective methods towards achieving sustainability. A number of studies have concentrated on the evaluation of safety of the physical environment and sustainability. Along this line of investigation, it may be concluded that safety and security should be considered as a prerequisite towards achieving sustainable development. Meanwhile, in terms of CPTED design strategies, Saville (2009) argued that it needs to move away from standardized CPTED theories in the direction of a holistic strategy to design, implement, and manage the societies. These mutations can be useful for the current system of place-based crime prevention for years to come.

Taken as a whole, a major recommendation from the authors is that crime and the fear of crime must be considered in the development process as effective indicators in achieving sustainability for communities. Crime prevention strategies if considered at the initial stage of each development may able to provide comprehensive sustainability outcomes namely environmental, social as well as economic benefits. Finally, recommendations are made not only for the consideration of safety in the development process, but also for the dissemination of 
crime prevention strategies that have proven to be successful. It needs to be noted that further and more studies need to be carried out in order to evaluate accurately the conflict between crime prevention by design strategies and sustainable development and address their measurements.

\section{References}

Abdullah, A. (1999). Crime Landscape: The Relationship of Victimisation and Fear of Crime with Residents' Territorial Functioning in High and Low Crime Rate Estates in Sheffield. Unpublished PhD Thesis, University of Sheffield, UK.

Armitage, R. (2000). An evaluation of secured by design housing within West Yorkshire-briefing note 7/00. London, Home Office.

Armitage, R. (2007). Sustainability versus safety: confusion, conflict and contradiction in designing out crime. In K. Pease, G. Farrell, K. J. Bowers \& S. D. Johnson (Eds.), Imagination for crime prevention: essays in honour of Ken Pease. Monsey: Criminal Justice Press.

Armitage, R., \& Gamman, L. (2009). Sustainability via Security: A New Look. Built Environment, 35(3), 297-301.

Armitage, R., \& Monchuk, L. (2009). Reconciling Security with Sustainability: The Challenge for Eco-Homes. Built Environment, 35(3), 308-327.

Berke, P. R., \& Conroy, M. M. (2000). Are We Planning for Sustainable Development? An Evaluation of 30 Comprehensive Plans. Journal of the American Planning Association, 66(1), 21-33.

Black, A. W. (2004, 19th February, 2004). The Quest for Sustainable, Healthy Communities. Paper presented at the Effective Sustainability Education: What Works? Why? Where Next? Linking Research and Practice, Sydney, Australia.

Bottoms, A. E., \& Wiles, P. (1997). Environmental Criminology, The Oxford Handbook of Criminology.Clarendon Press.

Brantingham, P. J., \& Brantingham, P. L. (1981). Urban Crime and Environmental Criminology, California: Sage.

Brantingham, P. L., \& Brantingham, P. J. (1993). Environment, routine and situation: toward a pattern theory of crime. In R. V. G. Clarke \& M. Felson (Eds.), Routine activity and rational choice (Vol. 5, pp. 259-294). New Jersey: Transaction Publishers.

Brantingham, P. L., \& Brantingham, P. J. (1998). Environmental criminology: from theory to urban planning practice. No.:, 7(1), 30.

Brantingham, P. L., \& Brantingham, P. J. (2001). The Implications of the Criminal Event Model for Crime Prevention. In R. F. Meier, L. W. Kennedy \& V. Sacco (Eds.), The process and structure of crime: criminal events and crime analysis. New Brunswick: Transaction Pub.

Campbell, S. (1996). Green cities, growing cities, just cities?Urban planning and the contradictions of sustainable development. Journal of the American Planning Association, 62, 296-312.

Carmona, M. (2001). Sustainable Urban Design-A Possible Agenda. In A. Layard, S. Davoudi \& S. Batty (Eds.), Planning for a Sustainable Future (pp. 165-192). London: Spon Press.

Clarke, R. V. (1992). Introduction. In R.V. Clarke (Ed.), Situational Crime Prevention: Successful Case Studies (p. 3-36). Albany, NY: Harrow and Heston.

Clarke, R. V. (1997a). Situational Crime Prevention: Successful Case Studies (second ed.). New York: Harrow and Heston.

Clarke, R. V. (1997b). The theory of crime prevention through environmental design: School of Criminal Justice, Rutgers University.

Clarke, R. V. G., \& Mayhew, P. (1980). Designing out crime. United Kingdom: Home Office Research Studies.

Coaffee, J., \& Bosher, L. (2008). Integrating counter-terrorist resilience into sustainability. Institution of Civil Engineers. Proceedings. Urban Design and Planning, 161(2), 75-83.

Cozens, P. (2007a). Planning, crime and urban sustainability. Sustainable Development and Planning III, 1, 187-196.

Cozens, P. (2007b). Public health and the potential benefits of crime prevention through environmental design.

New South Wales Public Health Bulletin, 18, 232-237. 
Cozens, P. (2008). Crime prevention through environmental design in Western Australia: planning for sustainable urban futures. International Journal of Sustainable Development and Planning, 3(3), 272-292.

Cozens, P. M. (2002). Sustainable urban development and crime prevention through environmental design for the British city, Towards an effective urban environmentalism for the 21st century. Cities, 19(2), 129-137.

Cozens, P. M. (2009). Education in Designing out Crime - A Case Study. Paper presented at the First International Design Out Crime Conference (iDOC'09), Perth, Western Australia.

Cozens, P. M., Saville, G., \& Hillier, D. (2005). Crime prevention through environmental design(CPTED): a review and modern bibliography. Property Management, 23(5), 328-356.

Cozens, P., \& Love, T. (2009). Manipulating Permeability as a Process for Controlling Crime: Balancing Security and Sustainability in Local Contexts. Built Environment, 35(3), 346-365.

Cozens, P., Hillier, D., \& Prescott, G. (1999). The sustainable and the criminogenic: the case of newbuild housing projects in Britain, Property Management, 17(3), 252-261.

Crowe, T. D. (1991). Crime Prevention Through Environmental Design: Applications of Architectural Design and Space Management Concepts, Boston: Butterworth-Heinemann.

Crowe, T. D. (2000). Crime prevention through environmental design: applications of architectural design and space management concepts (2end ed.): Butterworth-Heinemann.

Dewberry, E. (2003). Designing Out Crime: Insights from Ecodesign. Security Journal, 16, 51-62.

Dietrick, B. (1977). The environment and burglary victimization in a metropolitan suburb. Paper presented at the annual meeting of the American Society of Criminology Atlanta.

Du Plessis, C. (1999). The Links between Crime Prevention and Sustainable Development. Open House International, 24(1), 33-40.

Edwards, B. (2000). Sustainable housing: architecture, society and professionalism. In B. Edwards \& D. Turrent (Eds.), Sustainable Housing: Principles and Practice. London: Taylor \& Francis.

Gardiner, R. A. (1978). Design for safe neighborhoods. (National Institute of Law Enforcement and Criminal Justice. Law Enforcement Assistance Administration.

Garland, D. (1997). Of crimes and criminals: The development of criminology in Britain. In M. Maguire, R. Morgan \& R. Reiner (Eds.), The Oxford handbook of criminology (pp. 11-56). Oxford: Clarendon Press.

Geason, S., \& Wilson, P. R. (1989). Designing out crime: Crime prevention through environmental design, Canberra: Australian Institute of Criminology.

Glasson, J., \& Cozens, P. (2010). Making communities safer from crime: An undervalued element in impact assessment. Environmental Impact Assessment Review(doi:10.1016/j.eiar.2010.03.007).

Greenberg, S. W., Rohe, W. M., \& Williams, J. R. (1982). Safety in urban neighborhoods: A comparison of physical characteristics and informal territorial control in high and low crime neighborhoods, Population \& Environment, 5(3), 141-165.

Haigh, Y. (2006). Promoting Safer Communities through Physical Design, Social Inclusion and Crime Prevention through Environmental Design, Murdoch. (Centre for Social and Community Research)

Hedayati, M. (2009). Perception of Crime and an Assessment of Crime Prevention Through Environmental Design (CPTED) Elements in a Housing Area: A Case Study OF Minden Heights in Penang. Unpublished Msc Thesis, Universiti Sains Malaysia, Penang.

Hedayati, M., Abdullah, A., \& Maghsoodi, M. J. (2010). Theory and Practice of Residential Areas' Street Configuration and Burglary Vulnerability: A Review of the Literature. International Journal of Organizational Innovation, 3(2- Fall 2010), 178-198.

Higgins, N., \& Millard, B. (2009). Geographic patterns of crime. In A. Walker, J. Flatley, C. Kershaw \& D. Moon (Eds.), Home Office Statistical Bulletin-Crime in England and Wales 2008/09 (Vol. 1(11/09)). London: Home Office.

Holtz, S. (1998). Integrating Environmental, Social and Economic Policies. In J. Schnurr \& S. Holtz (Eds.), The Cornerstone of Development (pp. 283-293). Ottawa, Canada: IDRC.

Jackson, L. E. (2003), The relationship of urban design to human health and condition, Landscape and Urban Planning, 64, 191-200. 
Jacobs, J. (1961). The Death and Life of Great American Cities. New York: Random House.

Jeffery, C. R. (1971). Crime Prevention Through Environmental Design. Beverly Hills, CA: Sage.

Kaiser, E., Godschalk, D., \& Chapin, S. (1995), Urban land use planning, Chicago: University of Illinois Press.

Knepper, P. (2009), How Situational Crime Prevention Contributes to Social Welfare, Liverpool Law Rev, 30, $57-75$.

Knights, B., Pascoe, T., Henchley, A., \& Bre, W. (2002). Sustainability and crime Managing and recognising the drivers of crime and security.

Maclaren, V. W. (1996), “Urban sustainability reporting”, Journal of the American Planning Association, 62(2), 184-202.

Makarov, P. (2010). Intellectual capital as an indicator of a sustainable development. Journal of Sustainable Development, 3(3), 85-90.

Maslow, A. H. (1970). Motivation and personality (Third ed.). New York: Harper \& Row.

Mayhew, P., Clarke, R., Sturman, A., \& Hough, M. (1976). Crime as Opportunity (Home Office Research Study No. 34). London: HMSO.

Mega, V. (1996), Our city, our future: towards sustainable development in European cities, Environment and Urbanization, 8(1), 133.

Mora, P. (2008). Towards a Strategy of Crime Prevention Through Environmental Design in the City of Masaya, Nicaragua. McGill University - School of Urban Planning, Canada.

National Crime Prevention Institute. (1986). Understanding Crime Prevention, Stoneham: Butterworth Publishers.

National Institute of Justice. (1997). Solving Crime Problems in Residential Neighborhoods: Comprehensive Changes in Design, Management, and Use: National Institute of Justice, (U.S. Department of Justice. National Institute of Justice)

Neill, D. O., Rueda, R., \& Savage, J. (2009). Security Design for Sustainable Buildings and Campuses (Fisrt ed.), Massachusetts: Applied Risk Management (ARM).

Nes, A. v., \& Rueb, L. (2009). Spatial Behaviour in Dutch Dwelling Areas- How Housing Layouts Affects the Behaviour of its Users. Paper presented at the 7th International Space Syntax Symposium, Stockholm.

Newman, O. (1972). Defensible space; crime prevention through urban design, New York: Macmillan.

Newman, O. (1980). Community of Interest, New York: Anchor Press/Doubleday.

Newman, O. (1982). The Effects of Building Size on Personal Crime and Fear of Crime, Population and Environment, 5(4), 203-220.

Newman, O. (1996). Creating defensible space, Office of Policy Development and Research. Washington DC: US Department of Housing and Urban Development.

Nutter, J. B., \& Bevis, C. (1977). Changing Street Layouts to Reduce Residential Burglary. United States: Minnesota Crime Prevention Center.

Parnaby, P. (2007). Crime prevention through environmental design: financial hardship, the dynamics of power, and the prospects of governance, Crime Law Soc Change, 48, 73-85.

Poyner, B., \& Webb, B. (1991). Crime Free Housing, Butterworth Architecture.

Rhodes, W. M., \& Conly, C. (1981). Mobility: An Empirical Study, Environmental Criminology.

Sampson, R. J., \& Raudenbush, S. W. (1999). Systematic social observation of public spaces: A new look at disorder in urban neighborhoods. American Journal of Sociology, 105(3), 603-651.

Saville, G. (2009). SafeGrowth: Moving Forward in Neighbourhood Development. Built Environment, 35(3), 386-402.

Schneider, R. H., \& Kitchen, T. (2002). Planning for crime prevention: a transatlantic perspective. New York: Routledge.

Schneider, R. H., \& Kitchen, T. (2007). Crime Prevention in the Built Enviroment New York: Routledge. 
Shepard, A., \& Ortolano, L. (1996), Strategic environmental assessment for sustainable development, Environmental Impact Assessment Review, 16, 248-259.

Shu, C.-F. (2009). Spatial Configuration of Residential Area and Vulnerability of Burglary: Case Studies from UK and Taiwan, Paper presented at the 7th International Space Syntax Symposium, Stockholm.

Soberon, L. (1998). Concertación: Integrated Planning and Development in Peru. In J. Schnurr \& S. Holtz (Eds.), The Cornerstone of Development (pp. 263-281). Ottawa, Canada: IDRC.

Sorensen, D. W. M. (2003). The Nature and Prevention of Residential Burglary: A Review of the International Literature with An Eye Toward Prevention in Denmark.

Sorensen, S. L. (2007). Codifying CPTED: Moving Beyond Art to Science, In US Postal Service Training Program (Ed.).

Srinivasan, S., O'Fallon, L. R., \& Dearry, A. (2003). Creating healthy communities, healthy homes, healthy people: initiating a research agenda on the built environment and public health. American Journal of Public Health, 93(9), 1446.

Vanderschueren, F. (1998). Towards safer cities. United Nations Centre for Human Settlements (UNCHS) Habitat Debate, 4(1).

Walker, A., Flatley, J., Kershaw, C., \& Moon, D. (2009). Home Office Statistical Bulletin-Crime in England and Wales 2008/09 (Vol. 1(11/09)). London: Home Office.

Welsh, B. C., Farrington, D. P., \& O’Dell, S. J. (2010). Effectiveness of Public Area Surveillance for Crime Prevention: Security Guards, Place Managers and Defensible Space. Stockholm: Swedish National Council for Crime Prevention.

White, G. F. (1990). Neighborhood permeability and burglary rates. Justice Quarterly, 7, 57.

Wilson, J. Q., \& Kelling, G. L. (1982). The police and neighborhood safety: Broken windows. Atlantic Monthly, 127, 29-38.

\section{APPENDIX}

Table 1. Synergies between crime prevention and sustainability

\begin{tabular}{|l|l|}
\hline Crime Prevention & Sustainability \\
\hline Shared responsibility for crime & Shared responsibility for sustainability \\
\hline Offenders to acknowledge responsibility & Polluters to acknowledge responsibility \\
\hline Crime events promote social exclusion & Inequity in the security of communities \\
\hline $\begin{array}{l}\text { Reducing effects of crime through investment in } \\
\text { evidence and effectiveness }\end{array}$ & $\begin{array}{l}\text { Reducing environmental impacts through investment in } \\
\text { evidence and effectiveness }\end{array}$ \\
\hline $\begin{array}{l}\text { Reducing the impacts of crime through developing } \\
\text { products and systems which are more resistant to } \\
\text { criminal activity }\end{array}$ & $\begin{array}{l}\text { Promoting sustainability by developing products and } \\
\text { systems which are more environmentally and socially } \\
\text { responsible }\end{array}$ \\
\hline $\begin{array}{l}\text { The need for government strategies partnerships, } \\
\text { evidence-based action and accountability }\end{array}$ & $\begin{array}{l}\text { The need for government strategies, partnerships, best } \\
\text { practice and environmental and social responsibility }\end{array}$ \\
\hline Promoting quality of life issues & Understanding quality of life issues \\
\hline $\begin{array}{l}\text { Enhancing understanding of the ecology of crime and } \\
\text { environmental criminology }\end{array}$ & $\begin{array}{l}\text { Enhancing understanding of the ecology of the } \\
\text { environment }\end{array}$ \\
\hline $\begin{array}{l}\text { Use of the built environment to reduce opportunities } \\
\text { for crime and promote liveability }\end{array}$ & $\begin{array}{l}\text { Use of the built environment to reduce waste and } \\
\text { promote liveability and sustainability }\end{array}$ \\
\hline
\end{tabular}

Source: Cozens (2007a, p. 191) adapted from Dewberry (2003) 


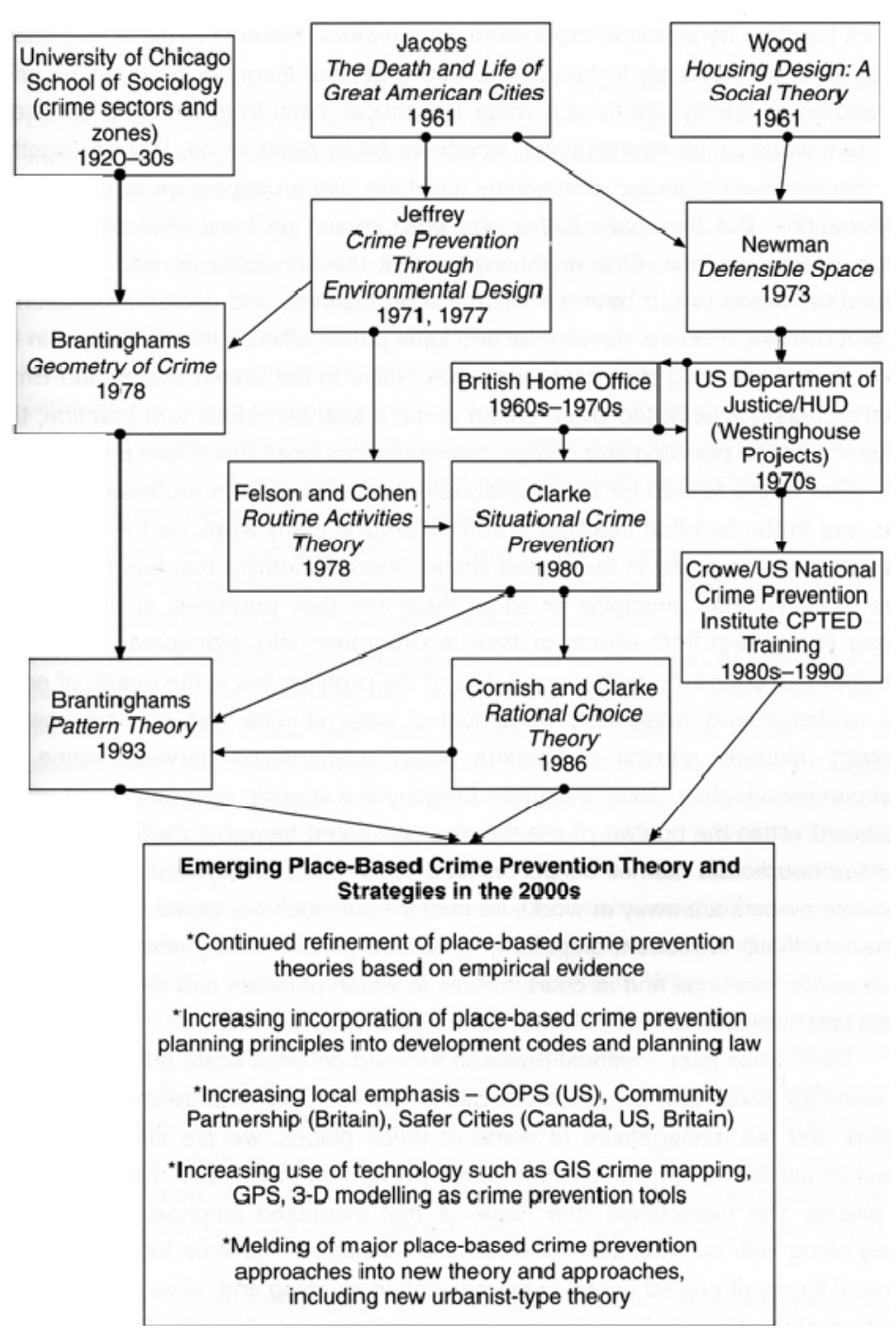

Figure 1. Major milestones in the development of place-based crime prevention theory Source: Schneider and Kitchen, 2002, p. 115 